ФОРМЫ

ПОЛИЦЕЙСКОЙ ДЕЯТЕЛЬНОСТИ

Таджибов В.P.

\title{
К ВОПРОСУ О СОЗДАНИИ И ПРАВОВОМ ПОЛОЖЕНИИ ЧАСТНЫХ ВОЕННЫХ КОМПАНИЙ В РОССИИ
}

4 астные военные компании (далее - ЧВК) возникли за рубежом более 40 лет назад. Мировой опыт деятельности показывает все возрастающее их влияние в решении экономических, политических и военных задач в интересах создавших их государств. Общее количество ЧВК в мире насчитывает более 450, они осуществляют деятельность более чем в 110 странах мира и совокупная численность их сотрудников составляет более 5 миллионов человек.

По данным Ассоциации по международным миротворческим операциям, большинство военных услуг ЧВК до 2014 года выполнялось в Ираке, Афганистане, Иордании, Кувейте, Объединенных Арабских Эмиратах и Колумбии.

В 2012 - 2014 гг. произошло резкое увеличение участия ЧВК в США, Великобритании, Франции, Бельгии, при этом функции их расширились за счет увеличения охраняемых военных объектов, государственных учреждений и высших должностных лиц иностранных государств. Ежегодный объем услуг, представляемых ЧВК и охранными компаниями, возрос с 200 миллиардов долларов США в 2010 году до 350 миллиардов долларов США в 2012 году. Достаточно отметить, что за первые 9 месяцев президентства Барака Обамы число вооруженных сотрудников компаний-подрядчиков Министерства обороны США выросло на 236\% - с 3184 до 10712.
В целях более полного понимания сущности деятельности ЧВК, в рамках данной статьи остановимся на понятии «ЧВК». В проанализированной нами литературе можно встретить различные названия: частные военизированные компании, частные военные компании, частные военные и охранные компании, частные военные контракторы, приватизационные военные фирмы и т.д.

В международном документе, известном как «Документ Монтре» и определяющим правовые обязательства функционирования ЧВК дается следующее определение частных военных и охранных компаний: «частные предпринимательские субъекты, которые оказывают военные и/или охранные услуги, независимо от того, как они себя характеризуют. Военные и охранные услуги включают, в частности, вооруженную охрану и защиту людей и объектов, например транспортных колонн, зданий и других мест; техобслуживание и эксплуатацию боевых комплексов; содержание под стражей заключенных; консультирование или подготовку местных военнослужащих и охранников». 1

\footnotetext{
1 Документ Монтре - «О соответствующих международно-правовых обязательствах и передовых практических методах государств, касающихся функционирования частных военных и охранных компаний в период вооруженного конфликта» http://daccess-dds-ny.un.org/doc.
} 
В военно-политическом словаре под редакцией Д.О. Рогозина ЧВК определяются так: «уполномоченные нанимающим государством негосударственные предприятия, специализирующиеся на выполнении ряда задач вооруженных сил, в том числе в локальных конфликтах». ${ }^{2}$

Исследователь В. Неелов дает обобщающее определение ЧВК: «негосударственные коммерческие структуры, оказывающие заказчику (в нашем случае - государству) военные, охранные, консалтинговые, логистические или иные услуги, в условиях военных конфрликтов и/или боевых действий». Мы согласны с данным определением, за исключением того, что ЧВК могут выполнять задачи не только в условиях военных конфликтов и боевых действий, но и в мирное время. ${ }^{3}$

Приведенные дефиниции в общих чертах дают представление о характере задач, стоящих перед ЧВК.

Создание и законодательное закрепление института частных военных компаний в России, по нашему мнению, становится актуальным - дискуссия о необходимости создания ЧВК продолжается уже более 2-х лет. Следует отметить, что создание ЧВК не является самоцелью, и не все западные модели управления военным делом могут быть привнесены в Россию. Для этого, прежде всего, необходим всесторонний научный анализ данной проблемы, в результате которого будет представлен оптимальный вариант решения данной проблемы. Настоящее исследование призвано ответить на следующие вопросы:

- Существует ли потребность и необходимость в создании ЧВК?

\footnotetext{
2 Война и мир в терминах и определениях. Военно-политический словарь / Под ред. Д.О. Рогозина. - М.: Вече, 2011.

${ }^{3}$ См.: Неелов В. Частные военные компании в России: опыт и перспективы использования. - СПб., 2013.
}

- Уменьшится ли нагрузка на бюджет, выделяемый на оборону и безопасность?

- Возможен ли эффрективный общественный, государственный (включая фринансовый и правовой) контроль за деятельностью ЧВК?

- Можно ли рассчитывать на увеличение занятости трудоспособного населения?

В перечень вопросов можно также включить и сугубо специальные, касающиеся военной и охранной деятельности, что значительно увеличит предмет изучения.

Президент РФ В.В. Путин, выступая 11 апреля 2012 г. В Государственной Думе, отметил, что создание ЧВК «действительно является инструментом реализации национальных интересов без прямого участия государства». Заместитель председателя Правительства РФ Д.О. Рогозин на заседании Военно-промышленной комиссии 20 октября 2012 г. в г. Тула предложил организовать межведомственную рабочую группу по созданию ЧВК. Внесенный 12 мая 2012 г. в Государственную Думу проект закона N2 62015-6 «О государственном регулировании создания и деятельности частных военных компаний» решением Комитета по обороне возвращен автору законодательной инициативы, в связи с отсутствием заключения Правительства РФ. C таким решением законодательного органа можно вполне согласиться в части необходимости основательной доработки данного закона. Дело не только в том, что деятельность ЧВК осуществляется в сорерах, затрагивающих основные функции государства, но и в том, что она предполагает значительные изменения в российском законодательстве.

Создание закона о ЧВК потребует дополнений и изменений в административном, уголовном, трудовом, налоговом и военном праве, а также необходимо учесть правовые позиции норм международного права. Для разработки зако- 
на такого уровня необходимо привлечь ученых- юристов, экономистов, военных специалистов, бизнесменов, а также представителей институтов гражданского общества.

Создание ЧВК не противоречит Конституции РФ, нормам международного права и соответствует задачам, вытекающим из Указа Президента РФ от 12 мая 2009 года №537 «О стратегии национальной безопасности Российской Федерации до 2020 года». Следует отметить, что Стратегия национальной безопасности представляет собой документ, который обусловливает организационно-правовую основу создания ЧВК и определяет основные сореры их деятельности.

В зависимости от сфреры деятельности, представляется возможным сделать вывод о том, насколько необходимы ЧВК в нашей стране. Во-первых, действуя за рубежом, ЧВК как неформальные, негосударственные структуры, содействуют обеспечению внешней политики и укреплению авторитета нашей страны в мировом сообществе. Во-вторых, продвижение и защита экономических интересов государства, бизнеса, фризических и юридических лиц, сотрудничество с зарубежными частными страховыми и охранными компаниями с целью правовой и фризической безопасности российских граждан указывает на экономическую составляющую деятельности ЧВК. Налоговые сборы от деятельности компа- ний также будут являться определенным вкладом в бюджет страны. В-третьих, с привлечением на работу в ЧВК лиц, уволенных на пенсию из числа военнослужащих Министерства обороны и других силовых ведомств, решаются вопросы трудоустройства значительного количества людей, то есть снижается социальная напряженность. Кроме того, в стране есть опыт привлечения на договорной основе частных охранных предприятий к профрилактике преступлений - в этой работе могут участвовать ЧВК. В - четвертых, обеспечение безопасности на железнодорожном, воздушном и водном транспорте; охрана нефтяных, газовых, энергетических систем; сопровождение конвоев с военными и гуманитарными грузами; тыловое обеспечение войск; консультирование и обучение военных специалистов. Все эти задачи могут эфрфективно решаться ЧВК. Обращая внимание на так называемые военно-охранные задачи, стоящие перед ЧВК, нельзя не обратить внимание на ситуацию, складывающуюся в мире. Современные военные конфликты, «цветные революции» получили название гибридных войн, которые включают в себя комбинации гражданской, партизанской, террористической, информационной войн. Страны НАТО в этих войнах широко используют ЧВК. Этот опыт требует всестороннего анализа и использования в противодействии агрессии.

\section{Библиография:}

1. Документ Монтре - «О соответствующих международно-правовых обязательствах и передовых практических методах государств, касающихся функционирования частных военных и охранных компаний в период вооруженного конфрлика», http://daccess-dds-nv.un.org/doc.

2. Война и мир в терминах и определениях. Военно-политический словарь. Под общ. ред. Рогозина Д.О. М., 2011.

3. Неелов В. Частные военные компании в России: опыт и перспективы использования. СПб., 2013.

4. Б. Михайленко А.М. Регулирование деятельности частных военных и охранных компаний в зонах вооруженных конфликтов. М.: Изд-во РАГС, 2010. 


\section{Полицейская деятельность 6 • 2014}

5. Саврыга К.П. Частные военные и охранные компании по международному праву. Международное право и международные организации. №4, 2013.

6. Мартьянов О. Подготовка кадров для частных военных компаний в учебных центрах США. Зарубежное военное обозрение. №6(783), 2012.

7. Харитонов А.Н. Контроль над преступностью в России: теория и практика. Монография. - Изд-во «Радуница», 2012.

8. Е. Ю. Бондаренко Международно-правовые аспекты военного плена в межгосударственных и российских нормативно- правовых актах конца XIX - XX вв. // Международное право и международные организации / International Law and International Organizations. - 2012. - 2. - С. $155-171$.

9. Куракин А.В. Социальная политика и российская полиция // NB: Российское полицейское право. - 2013. - 3. - C. 1 - 23. DOI: 10.7256/2306-4218.2013.3.8914. URL: http://www.enotabene.ru/pm/article_8914.html

\section{References (transliterated):}

1. Neelov V. Chastnye voennye kompanii v Rossii: opyt i perspektivy ispol'zovaniya. SPb., 2013.

2. B. Mikhailenko A.M. Regulirovanie deyatel'nosti chastnykh voennykh i okhrannykh kompanii v zonakh vooruzhennykh konfliktov. M.: Izd-vo RAGS, 2010.

3. Savryga K.P. Chastnye voennye i okhrannye kompanii po mezhdunarodnomu pravu. Mezhdunarodnoe pravo i mezhdunarodnye organizatsii. №4, 2013.

4. Mart'yanov O. Podgotovka kadrov dlya chastnykh voennykh kompanii v uchebnykh tsentrakh SShA. Zarubezhnoe voennoe obozrenie. №6(783), 2012.

5. Kharitonov A.N. Kontrol' nad prestupnost'yu v Rossii: teoriya i praktika. Monografiya. - Izd-vo «Radunitsa», 2012.

6. E. Yu. Bondarenko Mezhdunarodno-pravovye aspekty voennogo plena v mezhgosudarstvennykh i rossiiskikh normativno- pravovykh aktakh kontsa XIX - XX vv. // Mezhdunarodnoe pravo i mezhdunarodnye organizatsii / International Law and International Organizations. - 2012. 2. - C. $155-171$.

7. Kurakin A.V. Sotsial'naya politika i rossiiskaya politsiya // NB: Rossiiskoe politseiskoe pravo. - 2013. - 3. - C. 1 - 23. DOI: 10.7256/2306-4218.2013.3.8914. URL: http://www.e-notabene. ru/pm/article_8914.html 